\title{
'A green step forward: Eliciting consumers' purchasing decisions regarding green hotel accommodation in Australia.'
}

\author{
Abstract \\ This study identifies beliefs and additional constructs that contribute to the formation of \\ Australian residents' purchasing decisions of green hotel accommodation through the \\ lens of the Theory of Planned Behavior (TPB). A qualitative approach using focus \\ groups and open-ended questionnaires were employed to gain an in-depth \\ understanding of the beliefs of travelers in the South East region of Queensland, \\ Australia. The study utilizes thematic content analysis from three focus group \\ discussions with 15 participants. Benefits, concerns, referents, facilitators and barriers \\ were identified. Moreover, there was significant unprompted vagueness regarding the \\ green hotel practices. The results provided distinctive information concerning \\ Australian residents' beliefs about staying in green hotels. Moreover, the study \\ revealed that the TPB needs expansion to account for the lack of knowledge about \\ green hotel practices. The research adds to a growing body of literature on the use of \\ theory to study consumer behavior in the green hotel sector.
}

Keywords: Green hotels; beliefs; green hotel knowledge; the theory of planned behavior.

\section{Introduction}

With the growing awareness of environmental responsibility, many industries are attempting to implement effective green initiatives (Huang, Lin, Lai, \& Lin, 2014). This 'greening' of praxis is also gaining increased attention in the hotel sector (Han, Hsu, \& Sheu, 2010). The hotel sector has been associated with negative effects on the environment through the consumption of natural resources, the generation of greenhouse gases, and waste production (Alzboun, Khawaldah, Backman, \& Moore, 2016). Many hotels are attempting to reduce the level of negative environmental impacts, which has led to the emergence of 'green hotels'. The industry defines 'green hotels' as lodging properties that are committed to various environmental initiatives such as reducing energy and water consumption, and decreasing waste outputs (Rahman \& Reynolds, 2016). Green hotels strive to implement comprehensive 
environmental practices to create positive contributions for protecting the environment (Han \& Yoon, 2015). Rationales and benefits such as compliance with government policy and regulation, increased stakeholders pressure, competitive advantage and reputation enhancement in addition to corporate performance improvement and cost reduction justify the hotels’ desicion to adopt green practices (Barber \& Deale, 2014; Han \& Yoon, 2015; Rahman \& Reynolds, 2016).

Central to all these reasons are consumers, who generally acknowledge green hotels' practices by showing willingness to pay a premium, sacrificing their convenience, comfort and some luxury standards through the process (Barber \& Deale, 2014; Rahman \& Reynolds, 2016). Though their demand for green accommodation is still relatively low, some lodging consumers now search for hotels that demonstrate the evidence of the implementation of green practices (Rahman \& Reynolds, 2016). Thus, it is crucial to have improved understanding of consumer behavior of purchasing green accommodation, so that successful marketing and operation strategies that influence their purchasing choices could be implemented (Han et al., 2010).

Researchers have identified several factors that impact environmentally-friendly behavior including personal characteristics (e.g., gender, age and education), internal factors (e.g., beliefs, environmental responsibilities, green knowledge and values) and external factors such as economic, social, incentives, barriers and situational factors (e.g., price, location, healthy environment, time and effort) (Baker, Davis, \& Weaver, 2014; De Leeuw, Valois, Ajzen, \& Schmidt, 2015; Han et al., 2010; Kang, Stein, Heo, \& Lee, 2012; Miao \& Wei, 2013). Nevertheless, Han et al. (2010) and Miao and Wei (2013) argue that large variances in pro-environmental behavior can be attributed to internal factors. As such, this research focuses on internal factors, specifically, beliefs to provide distinctive information concerning consumers' behavior in the green hotel setting. 
Human social behavior is assumed to follow the beliefs that individuals hold regarding a specific behavior (Fishbein \& Ajzen, 2010). Consumer behavior literature indicates that beliefs play a critical role in the decision formation process (De Leeuw et al., 2015). Therefore, it is important to identify the beliefs underlying green purchasing behavior from a sound theoretical framework which could then usefully inform strategies to encourage such behavior.

One of the most influential theories that has been used to identify beliefs is the Theory of Planned Behavior (TPB). The TPB is a validated social-cognitive model of human behavior which is well suited to determine significant beliefs that impact intention and behavior (Ajzen, 1991; De Leeuw et al., 2015). The TPB assumes that human behavior is based on rational decision-making and is guided by three types of salient beliefs: beliefs about the benefits/concerns of performing the behavior (behavioral beliefs), beliefs about the normative expectations and actions of others (normative beliefs) and beliefs about the presence of factors that may facilitate or impede the performance of the behavior (control beliefs) (Fishbein \& Ajzen, 2010). Attitude, perceived norm, and perceived behavioral control are formed respectively based on these beliefs, and they lead to the formation of intention and behavior (Ajzen, 1991). Fishbein and Ajzen (2010) indicate that eliciting readily accessible beliefs would provide substantive information about the cognitive foundation of the behavior. In addition, this can assist in the identification of other constructs that affect decision making (Han \& Ryu, 2012). This study, therefore, aims to explore the behavioral, normative, and control beliefs and also identify if there are any additional constructs that would contribute to the formation of Australian consumers' purchasing decisions related to staying in green hotels. 


\section{Literature Review}

Increased attention to environmental concerns has stimulated interest in research related to green hotels (Chan, Hsu, \& Okumus, 2016). ‘Green hotels’ are lodging properties that are committed to various environmental practices such as saving energy, reducing water consumption and decreasing waste (Rahman \& Reynolds, 2016). Green hotels are becoming a growing niche in the competitive accommodation market (Han \& Yoon, 2015), with the world's leading hotel brands starting to embrace environmental initiatives globally in order to become green (Kang et al., 2012). This trend is not only confined to large hotel chains with several small and medium size lodging properties around the world participating in green programs to reflect their environmental responsibility (Rahman, Park, \& Chi, 2015). However, whilst some of these hotels have initiated changes to their practices, less attention has been paid to the role of consumer behavior in the green hotel context.

Although some studies indicate that consumer demand for green hotels has gradually increased (Chan et al., 2016), more rigorous consumer research in this field is needed. According to Myung, McClaren, and Li (2012), out of the 52 research articles identified in the hospitality sector, only 28 per cent focused on consumer behavior towards green practices. Similarly, Kim, Lee, and Fairhurst (2017) reported that out of the 146 articles reviewed, only 25.3 per cent were consumer centred. This supports recent calls to increase attention to environmental behavior in the green hotel sector (Gao, Mattila, \& Lee, 2016). One way in which researchers can investigate such behavior is to build on social psychological theories, for example the TPB (Ajzen, 1991; Fishbein \& Ajzen, 2010).

The TPB is one of the most widely applied theoretical frameworks used to predict human social behavior (Gao et al., 2016). According to the TPB, behavior is predicted by intention to engage in a certain behavior and perceived behavioral control (Ajzen, 1991). The model further proposes that intention is determined by the interaction of three distinct 
constructs: individuals' evaluation of the behavior (attitude), their perception of the social pressure to engage in that behavior (perceived norm), and their perception of the potential difficulties and obstacles of performing the behavior (perceived behavioral control), and that these constructs are underpinned by beliefs (Ajzen, 1991). Attitudes towards the behavior are underpinned by behavioral beliefs. Perceived norms are based on normative injunctive and descriptive beliefs. Perceived behavioral control is proposed to arise from control beliefs. Moreover, despite the TPB's general usefulness, the theory can be broadened and deepened through adding additional constructs to enhance the predictive power of behavior in different contexts (Ajzen, 1991).

Several researchers have verified and validated the TPB in various domains of environmental behavior and such applications are expanding. Examples include: recycling (White \& Hyde, 2011), green consumer behavior (Paul, Modi, \& Patel, 2016), energy saving (Chen, 2016), green restaurant choice ( Jang, Chung, \& Kim, 2015), and green hotel choice (Chen \& Peng, 2012; Chen \& Tung, 2014). One limitation with the majority of these studies is that few of them have examined beliefs underlying the core TPB constructs. Specifically, in the green hotel sector, most research only employed the direct constructs (attitude, perceived norms and perceived behavioral control) alone to determine their influence on intention and behavior (Chang, Tsai, \& Yeh, 2014; Chen \& Peng, 2012; Chen \& Tung, 2014; Han, 2015; Han \& Yoon, 2015; Teng, Wu, \& Liu, 2015). Only three studies elicited consumers' beliefs related to green accommodation purchase (Han et al., 2010; Han \& Kim, 2010; Kim \& Han, 2010). This is unfortunate, as beliefs are viewed as the ultimate psychological determinants of behavior (Fishbein \& Ajzen, 2010).

According to De Leeuw et al. (2015), recognizing the subjective beliefs people hold towards an issue and how these beliefs influence their behavior is crucial for researchers in different fields. Peach, Jimmieson, and White (2005) stated that a key strength of the TPB 
lies in its capability to detect the core beliefs that stir a certain behavior. Beliefs may vary from behavior to behavior and from population to population (Ajzen, 1991). Therefore, to determine the actual beliefs of the target population and to gain further information about the foundations of their behaviors integrating belief constructs is essential (Fishbein \& Ajzen, 2010). As more consumers have started to understand that their purchasing behavior impacts the environment directly, it is important to investigate the behaviors of green consumers that are connected explicitly to their beliefs (Fornara, Pattitoni, Mura, \& Strazzera, 2016).

As mentioned previously in the literature review, the TPB recognizes three types of beliefs, namely behavioral, normative, and control beliefs (Ajzen, 1991). In the green hotel context, some studies have identified environmental protection, social responsibility, performing environmental friendly practices and enjoying environmental friendly products, and healthy amenities as consumers' behavioral beliefs related to their stay at green hotels (Han et al., 2010; Han \& Kim, 2010). When consumers perceive that their green purchasing decisions will benefit themselves, others, and/or the environment, they tend to show more intention to behave in an environmentally responsible manner (Han et al., 2010; Line \& Hanks, 2015). This indicates that consumers with environmental protection-oriented beliefs are more likely to be engaged in environmental behavior. For instance, Lee and Oh (2014) identified that beliefs related to helping protect the environment would significantly affect individuals’ decisions to stay at a green hotel.

As for normative beliefs, individuals are more likely to be engaged in a behavior if it is believed to be generally supported and done by significant others. Individuals regularly examine the behavior of others around them, and use them as a reference for their own actions, as this can serve as a strategy to modify their behavior (Gockeritz et al., 2009). In the original framework of the TPB, the normative beliefs referred only to what was supported or not supported by important people (Injunctive normative beliefs). Yet researchers highlighted 
that the concept of norms should be represented more extensively, referring to what is commonly done in addition to what is supported and not supported by significant others (Gockeritz et al., 2009). Therefore, Fishbein and Ajzen (2010) modified the framework of the TPB by differentiating between normative descriptive beliefs and normative injunctive beliefs and adding both beliefs to the TPB framework. This implies that although both beliefs rise from the desire to be accepted by others, they work through distinct processes (Gockeritz et al., 2009).

Research in the green hotel context has commonly studied the injunctive normative beliefs, and identified family/relatives, friends, and colleagues as salient referents (Han et al., 2010; Han \& Kim, 2010; Kim \& Han, 2010). As for descriptive normative beliefs, scholars have reported that beliefs about the others' involvement in environmental behaviors (descriptive normative beliefs) have a strong positive correlation with one’s own proenvironmental behavior (Gockeritz et al., 2009). De Leeuw et al. (2015) reported that descriptive normative beliefs explained 60 per cent of the variance in descriptive norms in the pro-environmental behavior of high-school students. These findings indicate that others' environmental behaviors were positively associated with individuals' engaging in such behaviors.

Regarding control beliefs, research in green hotels has identified price, time, effort, and the hotel location as control beliefs that would affect the purchase of green hotel accommodation (Han et al., 2010; Han \& Kim, 2010). These beliefs regarding the relative ease or difficulty of engaging in green consumption would be veiwed as vital in the consumer's decisions whether or not to engage in such behavior.

Therefore, this paper aimes to explore the following research questions: (1) What are the behavioral, normative, and control beliefs that impact Australian consumers’ purchasing 
decisions related to staying in green hotels? (2) What other constructs would affect their green accommodation purchasing decisions?

\section{Research Paradigm and Methodology}

The current research aims to understand 'significant beliefs and constructs underlying environmentally friendly behavior in the green hotels setting'. The current research is based on an objective ontology with a post-positivist epistemological approach. The post-positivist paradigm suggests that there is a 'real' reality which can be understood in a probable and uncertain manner (Denzin \& Lincoln, 2011). Although quantitative methods are primarily used in post positivist research, qualitative methods can also be employed (Denzin \& Lincoln, 2011). Within this paradigm, qualitative methods provide multiple viewpoints by asking open questions about individuals’ beliefs and perspectives regarding a specific topic (Roulston, 2010). Creswell (2009) states that post-positivists should begin their research with a theory, collect data to verify the theory so as to be able to gain a fuller understanding of the world. Accordingly, this research employed qualitative methods through the lens of the TPB to explore consumers’ beliefs regarding green hotels.

According to the TPB, beliefs that are accessible in memory create the principal considerations that guide behaviors (Fishbein \& Ajzen, 2010). Therefore, researchers should identify beliefs that spontaneously come to the participants' minds when they think about a specific behavior. To determine a population’s readily accessable beliefs, Fishbein and Ajzen (2010) recommend researchers to conduct an elicitation study on a small sample of individuals representing the research population and perform a content analysis of the responses to rank-order the beliefs. Following the recommendation of Fishbein and Ajzen, a qualitative approach using focus groups and open-ended questionnaires was used to gain an 
in-depth understanding of the beliefs contributing to the formation of Australian consumers' buying decisions related to staying in green hotels.

A focus group is defined as a research technique that allows researchers to gather data through group interaction (McGehee \& Santos, 2005). Generally understudied or new topic areas of research benefit from this method as it can provide in-depth understanding of the phenomenon and offer perceptual information as a precursor for further research (Huang \& Hsu, 2005). This method also has an advantage of bringing together a number of research participants simultaneously and gathering information through understanding how they feel or think about a certain issue (Krueger \& Casey, 2010; Siu, Lee, \& Leung, 2013).

Nevertheless, Fishbein and Ajzen (2010) argue that the focus group technique alone is not sufficient, and add that accessible beliefs should be elicited through a free-response format in which individuals list the beliefs that come readily to their mind. Therefore, in addition to focus groups, an open-ended questionnaire method was also used.

Australian active travelers who are 18 years and above were asked to participate in three focus groups. As this study aimed to ensure that a broad range of different beliefs about green hotels was identified, therefore, maximum variation sampling (Patton, 2002), was employed to ensure respondents ranged in age, gender and profession. Participants were recruited via snowball sampling (Patton, 2002). The sampling frame used in this research was travelers who had spent at least one night in a hotel in the last year, and who were willing to stay in a green hotel in the near future.

The focus group sessions were conducted in English at a local church hall in the South East region of Queensland. The duration of the sessions varied between 45 and 60 minutes. All participants were briefed about the study before the focus group session and debriefed at the end of the session. To ensure a shared understanding about the current discussion, participants were provided with a clear definition of green hotels. Green 
hotels are defined as hotels that diligently practice environmental management including recycling waste, towel and linen reuse programs, low-flow taps and shower-heads, automatic climate control and light sensors, and natural ventilation (Rahman \& Reynolds, 2016). The discussions were facilitated by the researcher and were audio-recorded.

Moreover, at the end of the focus group discussion, open-ended questions were handed to the participants which aimed to elicit their personal beliefs in a free response format (Fishbein \& Ajzen, 2010). The participants were given five minutes to document their thoughts about behavioral beliefs about the benefits and concerns; normative beliefs about those who would support and not support; normative beliefs about those who would stay or not stay; and the facilitators and barriers to staying in a green hotel. Finally, participants were asked to add any further information that would affect their decision to stay at a green hotel in the future.

The research involved three groups with a total of 15 participants. Of these, eight were females and seven were males. As illustrated in Table 1, the majority of participants (eight participants) were aged above 50 years old, the next largest group (four participants) were aged between 25 and 34. The final part of Table 1 lists a selection of the participants' employment.

Insert Table 1 near here

A semi-structured guide was developed according to the TPB guidelines (Fishbein \& Ajzen, 2010) to guide the discussions, see Table 2. Questions were designed to encourage participants to discuss issues related to staying in a green hotel including benefits and concerns, facilitators and barriers, and significant others who would support staying in a green hotel and who would themselves stay at such hotels. Towards the end, a probing 
question was asked to gain rich and detailed information about additional factors that would affect their green accommodation purchasing decisions.

Insert Table 2 near here

Recordings of participants’ responses were transcribed verbatim immediately after each focus group. The responses of the open ended questionnaires and the focus group discussion data were then evaluated using thematic content analysis (Fishbein \& Ajzen, 2010). Firstly, a content analysis of the responses of the open ended questionnaires was conducted using Nvivo 10 software. As recommended by Fishbein and Ajzen (2010), descriptive categories were identified and systematically coded for each of the TPB belief components and additional constructs. Following that, a frequency count was conducted and the constructs were then arranged in descending order. Secondly, analysis considered the extent to which participants elaborated upon the issue in their discussion using the focus groups transcripts. The results of the coding process were reviewed by the three researchers in order to enhance the reliability of the codes (Siu et al., 2013). Due to the framework provided by the TPB, limited discussion was required to reach a consensus among the researchers (Fraser et al., 2010).

\section{Results}

The content analysis identified the categories of (1) positive and negative outcomes of performing the behavior, (2) of individuals or social groups who serve as social referents, (3) of easy and difficult circumstances in which to perform the behavior, and (4) other constructs that will affect consumers' decisions to stay at a green hotel. Table 3 provides a summary of the key categories, beliefs (including the number of times a belief was listed), and example quotations for the TPB beliefs and the additional construct.

Insert Table 3 near here 
The environmental benefits from staying in a green hotel drew most attention from the participants as three environmental beliefs emerged, with the first one being "protecting the environment” followed by "fulfilling environmental obligations", and "concern for future generations". Personal benefits seemed not to be a dominant belief as "staying in a healthy environment” was mentioned by only three participants. Despite the recognition of these benefits of staying at a green hotel, most participants were concerned about possible 'greenwashing'. Of the three focus groups, seven participants indicated that they were not quite convinced that hotels are truly as green as they claimed and that they might be deceived by such claims. Moreover, some participants stated their concerns about compromizing on luxury and comfort if they stay in a green hotel.

In terms of normative beliefs, most participants considered "family and relatives" as a source of social influence that would support their stay at a green hotel. Other sources of social influence that were mentioned were “younger generation”, “colleagues”, and “employers”. Most participants indicated that none would not support their staying in a green hotel. As for referents who would actually stay in a green hotel, participants further identified “family” followed by “younger generation”, and “colleagues”. Moreover, participants considered "older generation" as referents who would not stay at a green hotel. According to the participants, older generation might not be interested in environmental issues and would not care about staying at a green hotel.

Convenient location was the most frequently mentioned control belief that facilitated the decision to stay at a green hotel. This was followed by "standardization” of environmental practices in green hotels. In terms of barriers, 13 participants indicated that the "high price" of green hotels would inhibit them from staying at a green hotel. According to them, green hotels might add extra expenses for implementing green practices, so it was quite reasonable that they indicated price as the number one behavioral inhibitor of staying at a green hotel. 
An interesting and worthy to note finding was that the majority of participants indicated that they lacked information about the environmental practices that green hotels were implementing. 13 out of 15 participants indicated that they needed to have better understanding of such practices. Hence, “Green Hotel Knowledge” was viewed as an additional construct that would affect their decision to stay at a green hotel.

\section{Discussion}

The present study explored the underlying beliefs that inform Australian residents’ decision to choose a green hotel. The study objectives are achieved. Limited research has been conducted previously about consumers’ decision formation in the green hotel context (Han et al., 2010). To the best of the authors' knowledge, this study was the first attempt to employ TPB to elicit the beliefs of Australian consumers about staying at green hotels. Importantly, additional constructs which would influence Australian residents' purchasing decisions related to choosing green accommodation were identified. The findings are of definite interest because they provide initial and unique perspectives on developing strategies to encourage such behavior.

Within the context of the Theory of Planned Behavior (TPB), most of the benefits related to behavioral beliefs were environmental centred. Participants mentioned benefits related to the environment more than personal benefits of staying at a green hotel. Participants clearly identified the environmental benefits of staying at a green hotel to protecting the environment, fulfilling environmental obligations and showing concern for future generations. These beliefs have been reported in research as factors that affect environmental consumer behavior in different contexts (De Leeuw et al., 2015; Kim \& Han, 2010). In a study of environmental beliefs, De Groot and Steg (2007) reported that participants linked the consequences of environmental problems with their own actions. This can be related to their belief that by acting in a pro-environmental manner, they may 
contribute to protecting the planet and leaving a better environment for future generations (Lee, Hsu, Han, \& Kim, 2010). There is a message here for the hotel marketers to send carefully selected messages with a focus on the positive impacts of green hotels on the environment.

As for personal benefits, participants indicate that being in a healthy environment was one of the benefits of staying in a green hotel. This was supported by the literature as studies indicate that consumers perceive staying at a green hotel as experiencing a healthy, environmentally friendly atmosphere (Han et al., 2010; Kim \& Han, 2010). Moreover, in the green restaurants context, where the same practices could be applied in the food and beverage areas in the hotel industry, literature indicates that customers often dine in green restaurants to enjoy a healthy environment (Jang et al., 2015).

Regarding personal concerns, results indicate that consumers were hesitant to stay at a green hotel due concerns about greenwashing. Consumers in previous studies were found to be sceptical about the hotels’ environmental claims (Baker et al., 2014). Specifically, Rahman et al. (2015) demonstrated that promoting green practices without integrating them holistically throughout the hotel can make consumers skeptical. Consumers often criticize hotels for their shallow implementation of green practices, with actions primarily aiming to reduce costs, effectively at the guests' expense (Baker et al., 2014). According to a study conducted in California, more than 30 per cent of travelers were suspicious about the hotels' green claims (Tierney, Hunt, \& Latkova, 2011). The same study reported that one in every three travelers was concerned about greenwashing. Thus, greenwashing is a major dilemma in the hotel industry as consumers perceive that hotels implement green practices as a mean of public relations without having a major substance (Rahman et al., 2015; Tierney et al., 2011). 
Participants were also concerned with compromizing on their luxury and comfort when staying in a green hotel. The literature indicates that hotel guests might perceive green practices as involving a sacrifice of luxury and comfort (Baker et al., 2014; Kang et al., 2012) as this sector establishes its business on perceived luxury and indulgence. For instance, a study by Line and Hanks (2015) reported a significant negative relationship between consumers' beliefs about luxury and their attitudes and behaviors towards staying in a green hotel. Some green initiative implemented in hotels give the impression of compromized quality (Rahman \& Reynolds, 2016). Moreover, in a relevant study, Rahman et al. (2015) found that consumers linked green hotels with lower levels of comfort and inconvenience. Therefore, hotel managers should encourage consumers’ participation in green programs by aligning their hotel's green messages with competing motives of guests such as personal comfort and luxury (Miao \& Wei, 2013).

A range of individuals (e.g., family, relatives and colleagues) were identified as sources of support for staying at a green hotel, consistent with other TPB studies (Han et al., 2010; Han \& Kim, 2010). However, this study found that family and relatives were the main group reported as supporting to stay in a green hotel. The younger generation has also been identified as key supportive referents, complementing recent research highlighting their potentially persuasive role in encouraging environmental purchasing decisions (Muralidharan, Rejón-Guardia, \& Xue, 2016). In their study, Fielding and Head (2012) associated young Australians’ environmental behavior with their environmental concern and knowledge. In addition, De Leeuw et al. (2015) stated: "Young people are a critical stakeholder, since they bear the burden of past and current negligence towards the environment. At the same time, they represent a powerful engine for behavior change” (p.128). 
Regarding descriptive normative beliefs, to the best of the authors' knowledge, this study was the first attempt to elicit descriptive normative beliefs in the green hotel context. For the important referents who would stay in a green hotel, the strongest referents that emerged were family and relatives and this was also reported by De Leeuw et al. (2015) who used the TPB to identify major beliefs underlying pro-environmental behavior. Another referent group that emerged was the younger generation. This referent group has been studied in consumer behavior research which indicated that young people respond to environmental threats with personal responsibility (De Leeuw et al., 2015; Huang et al., 2014). As for the important referents who would not stay at a green hotel, the main emerging referent was the older generation. Although most studies in the literature support this belief, in the green restaurant context, for instance, $\mathrm{Hu}$, Parsa, and Self (2010) found that individuals in older age groups tend to patronize green restaurants.

In examining control beliefs, participants were able to clearly describe the key factors that would facilitate their decision to stay in a green hotel, particularly noting that the convenient location of the green hotel was essential in their purchasing decisions. Similar findings have been reported in previous TPB studies in the green hotel context (Han et al., 2010; Han \& Kim, 2010; Kim \& Han, 2010). Another major facilitator to emerge was the importance of standardization of environmental programs in such hotels. Jarvis, Weeden, and Simcock (2010) indicated that a firm’s engagement with environmental accreditation requirements has a significant impact on consumers. More specifically, in the green hotel context, hotel managers should affiliate with third-party certifications that ensure the hotel meets certain standards, which will assist in confirming the hotel's environmental credibility in the eyes of consumers (Rahman et al., 2015).

Congruent with the identified facilitators, the main barrier to staying in a green hotel was the high price, which is a common finding in previous TPB studies (Han et al., 2010; 
Han \& Kim, 2010; Kim \& Han, 2010). In fact, consumers associate green hotels with higher price premiums (Jarvis et al., 2010). Individuals might be willing to engage in environmentally friendly behaviors, but they may act otherwise when it comes to paying extra money (Myung, 2016). In their article, Kuminoff, Zhang, and Rudi (2010) argue that although going green can decrease a hotel's rate of energy and water consumption, the adaptation process requires large fixed costs for installing appliances, as well as higher operating costs associated with purchasing environmentally friendly products. These costs may, in turn, be passed on to consumers through charging higher room rates. Yet, in hotel studies, Manaktola and Jauhari (2007) highlighted that only 15 per cent of consumers were willing to pay premiums for environmental practices. This is important for hoteliers to understand, as consumers hold a perception that green hotels cost more to stay at than traditional ones (Millar, Mayer, \& Baloglu, 2012). Therefore, hotel marketers should acknowledge this issue and aim to price their rooms competitively as price may be driving consumers away from green hotels (Millar et al., 2012).

As for the additional constructs highlighted through the elicitation study, most participants indicated that their lack of knowledge about the implementation of environmental practices in green hotels impedes their decisions concerning staying in such hotels. This has also been reported in other studies (Chen \& Peng, 2012).Green hotels and their practices would influence their intentions and planning processes (Chen \& Peng, 2012). In green restaurant studies, Hu et al. (2010) reported that consumer knowledge of environmental initiatives was a significant determinant of intention to visit green restaurants. In the same context, Jang, Kim, and Bonn (2011) indicated that the primary reason for consumers not visiting green restaurants was a lack of knowledge about such restaurants. In order to take a pro-environmental action (i.e. staying at a green hotel), consumers need relevant knowledge regarding the green programs implemented in such hotels. Therefore, 
hotel marketers should motivate their consumers to engage in green programs through emphasizing the environmental aspects of the programs (Goldstein, Griskevicius, \& Cialdini, 2007).

\section{Conclusion and Implications}

The results of this study offer new insights into the determinants of consumer behavior in the green hotel sector that could be of interest to researchers and practitioners. As an exploratory study, the research aimed to identify salient beliefs to be used in the development of future quantitative studies. The study was able to use the theoretical foundation of the TPB to develop an instrument to obtain a new set of items for belief constructs provided through a qualitative elicitation study. Moreover, this research offered insights related to extending the TPB model as the study revealed that the model arguably needs extension and account for "Green Hotel Knowledge”.

In terms of the implications of the current study for practitioners, the results would assist hotels which are engaged in green programs in building effective marketing strategies based on the salient beliefs of consumers, particularly in the Australian context. For example, the results specify that environmental benefits are more significant than personal benefits, therefore, marketers should implement green campaigns highlighting the importance of environmental protection to influence green purchasing behaviors. By doing so, consumers may build stronger beliefs that they will fulfil their environmental obligations if they choose green accommodation.

The results of this study also indicate that additional education about some of the green practices employed by hotels would be beneficial. While most of the participants in this study held positive perceptions of green hotels, some expressed their concerns about compromizing their comfort and luxury and having to incur extra expenses when staying in 
such hotels. Hotel managers need to educate their potential consumers that the implementation of green practices does not necessarily compromize quality of service and that the prices charged by green hotels are reasonable.

As for the younger generation, the study findings reinforce the importance of targeting this segment. Hoteliers have to consider this group as one of their potential target markets since they have increasing purchasing power, and they have a major influence on their families’ purchasing decisions.

Most significantly, the findings of this study reveal that it is important for hotels to make their green practices visible to consumers. Hotel managers need to actively inform consumers of their green practices via various information sources. They should develop promotional campaigns that effectively communicate the hotel's comprehensive green programs to ensure that consumers are well-informed. They also need certification by independent third parties, and communicate this to their guests. These efforts may help consumers to become better acquainted with the green practices implemented in green hotels which will assist them to make better-informed purchasing decisions. 


\section{References}

Ajzen, I. (1991). The Theory of Planned Behavior. Organizational Behavior and Human Decision Processes, 50, 179-211.

Alzboun, N., Khawaldah, H., Backman, K., \& Moore, D. (2016). The effect of sustainability practices on financial leakage in the hotel industry in Jordan. Journal of Hospitality and Tourism Management, 27, 18-26. doi:http://dx.doi.org/10.1016/j.jhtm.2016.03.001

Baker, M., Davis, E., \& Weaver, P. (2014). Eco-friendly Attitudes, Barriers to Participation, and Differences in Behavior at Green Hotels. Cornell Hospitality Quarterly, 55(1), 89-99. doi:10.1177/1938965513504483

Barber, N., \& Deale, C. (2014). Tapping Mindfulness to Shape Hotel Guests' Sustainable Behavior. Cornell Hospitality Quarterly, 55(1), 100-114. doi:10.1177/1938965513496315

Chan, E., Hsu, C., \& Okumus, F. (2016). Environmental Management Research in Hospitality. International Journal of Contemporary Hospitality Management, 28(5), 886-923.

Chang, H., Tsai, H., \& Yeh, S. (2014). Evaluation of Green Hotel Guests' Behavioral Intention. Advances in Hospitality and Leisure,10(10), 75-89.

Chen, A., \& Peng, N. (2012). Green Hotel Knowledge and Tourists' Staying Behavior. Annals of Tourism Research, 39(4), 2211-2216. doi:10.1016/j.annals.2012.07.003

Chen, M. (2016). Extending the Theory of Planned Behavior Model to Explain People's Energy Savings and Carbon Reduction Behavioral Intentions to Mitigate Climate Change in Taiwan-Moral Obligation Matters. Journal of Cleaner Production, 112(2), 1746-1753. doi:10.1016/j.jclepro.2015.07.043

Chen, M., \& Tung, P. (2014). Developing an Extended Theory of Planned Behavior Model to Predict Consumers’ Intention to Visit Green Hotels. International Journal of Hospitality Management, 36, 221-230. doi:10.1016/j.ijhm.2013.09.006

Creswell, J. (2009). Research Design: Qualitative, Quantitative, and Mixed Methods Approaches (3rd ed.). Thousand Oaks, California: Sage.

De Groot, J., \& Steg , L. (2007). General Beliefs and the Theory of Planned Behavior: The Role of Environmental Concerns in the TPB. Journal of Applied Social Psychology, 37(8), 1817-1836.

De Leeuw, A., Valois, P., Ajzen, I., \& Schmidt, P. (2015). Using the Theory of Planned Behavior to Identify Key Beliefs Underlying Pro-Environmental Behavior in High- 
School Students: Implications for Educational Interventions. Journal of Environmental Psychology, 42, 128-138. doi:10.1016/j.jenvp.2015.03.005

Denzin, N., \& Lincoln, Y. (2011). The Sage Handbook of Qualitative Research (4th ed.). Thousand Oaks, California: Sage.

Fielding, K., \& Head, B. (2012). Determinants of Young Australians’ Environmental Actions: the Role of Responsibility Attributions, Locus of Control, Knowledge and Attitudes. Environmental Education Research, 18(2), 171-186.

Fishbein, M., \& Ajzen, I. (2010). Predicting and Changing Behavior: The Reasoned Action Approach. New York: Taylor \& Francis.

Fornara, F., Pattitoni, P., Mura, M., \& Strazzera, E. (2016). Predicting Intention to Improve Household Energy Efficiency: The Role of Value-Belief-Norm Theory, Normative and Informational Influence, and Specific Attitude. Journal of Environmental Psychology, 45, 1-10. doi:10.1016/j.jenvp.2015.11.001

Fraser, R., Johnson, K., Hebert, J., Ajzen, I., Copeland, J., Brown, P., \& Chan, F. (2010). Understanding Employers’ Hiring Intentions in Relation to Qualified Workers with Disabilities: Preliminary Findings. Journal of Occupational Rehabilitation, 20(4), 420-426. doi:10.1007/s10926-009-9220-1

Gao, Y., Mattila, A., \& Lee, S. (2016). A Meta-Analysis of Behavioral Intentions for Environment-Friendly Initiatives in Hospitality Research. International Journal of Hospitality Management, 54, 107-115. doi:http://dx.doi.org/10.1016/j.ijhm.2016.01.010

Gockeritz, S., Schultz, W., Rendon, T., Cialdini, R., Goldstein, N., \& Griskevicius, V. (2009). Descriptive Normative Beliefs and Conservation Behavior: The Moderating Roles of Personal Involvement and Injunctive Normative Beliefs. European Journal of Social Psychology, 40, 514-523. doi:10.1002/ejsp.643

Goldstein, N. J., Griskevicius, V., \& Cialdini, R. B. (2007). Invoking social norms: A social psychology perspective on improving hotels' linen-reuse programs. Cornell Hotel and Restaurant Administration Quarterly, 48(2), 145-150.

Han, H. (2015). Travelers' Pro-Environmental Behavior in a Green Lodging Context: Converging Value-Belief-Norm Theory and the Theory of Planned Behavior. Tourism Management, 47, 164-177. doi:10.1016/j.tourman.2014.09.014

Han, H., Hsu, T., \& Sheu, C. (2010). Application of the Theory of Planned Behavior to Green Hotel Choice: Testing the Effect of Environmental Friendly Activities. Tourism Management, 31(3), 325-334. doi:10.1016/j.tourman.2009.03.013 
Han, H., \& Kim, Y. (2010). An Investigation of Green Hotel Customers' Decision Formation: Developing an Extended Model of the Theory of Planned Behavior. International Journal of Hospitality Management, 29(4), 659-668. doi:10.1016/j.ijhm.2010.01.001

Han, H., \& Ryu, K. (2012). The Theory of Repurchase Decision-Making (TRD): Identifying the Critical Factors in the Post-Purchase Decision-Making Process. International Journal of Hospitality Management, 31(3), 786-797. doi:10.1016/j.ijhm.2011.09.015

Han, H., \& Yoon, H. (2015). Hotel Customers' Environmentally Responsible Behavioral Intention: Impact of Key Constructs on Decision in Green Consumerism. International Journal of Hospitality Management, 45, 22-33. doi:10.1016/j.ijhm.2014.11.004

Hu, H., Parsa, H., \& Self, J. (2010). The Dynamics of Green Restaurant Patronage. Cornell Hospitality Quarterly, 51(3), 344-362.

Huang, H., Lin, T., Lai, M., \& Lin, T. (2014). Environmental Consciousness and Green Customer Behavior: An Examination of Motivation Crowding Effect. International Journal of Hospitality Management, 40, 139-149. doi:10.1016/j.ijhm.2014.04.006

Huang, S., \& Hsu, C. (2005). Mainland Chinese Residents' Perceptions and Motivations of Visiting Hong Kong: Evidence from Focus Group Interviews. Asia Pacific Journal of Tourism Research, 10(2), 191-205.

Jang, S., Chung, J., \& Kim, Y. (2015). Effects of Environmentally Friendly Perceptions on Customers' Intentions to Visit Environmentally Friendly Restaurants: An Extended Theory of Planned Behavior. Asia Pacific Journal of Tourism Research, 20(6), 599618. doi:10.1080/10941665.2014.923923

Jang, Y., Kim, W., \& Bonn, A. (2011). Generation Y Consumers' Selection Attributes and Behavioral Intentions Concerning Green Restaurants. International Journal of Hospitality Management, 30(4), 803-811.

Jarvis, N., Weeden, C., \& Simcock, N. (2010). The Benefits and Challenges of Sustainable Tourism Certification: A Case Study of the Green Tourism Business Scheme in the West of England. Journal of Hospitality and Tourism Management, 17(1), 83-93. doi:http://dx.doi.org/10.1375/jhtm.17.1.83

Kang, K., Stein, L., Heo, C., \& Lee, S. (2012). Consumers' Willingness to Pay for Green Initiatives of the Hotel Industry. International Journal of Hospitality Management, 31(2), 564-572. doi:10.1016/j.ijhm.2011.08.001

Kim, S., Lee, K., \& Fairhurst, A. (2017). The Review of “Green” Research in Hospitality, 2000-2014: Current Trends and Future Research Directions. International Journal of 
Contemporary Hospitality Management, 29(1), 226-247. doi:10.1108/IJCHM-112014-0562

Kim, Y., \& Han, H. (2010). Intention to Pay Conventional-Hotel Prices at a Green Hotel - A Modification of the Theory of Planned Behavior. Journal of Sustainable Tourism, 18(8), 997-1014. doi:10.1080/09669582.2010.490300

Krueger, R., \& Casey, M. (2010). Focus Group Interviewing: Handbook of Practical Program Evaluation (3rd ed). San Francisco (CA): Jossey-Bass.

Kuminoff, N., Zhang, C., \& Rudi, J. (2010). Are Travelers Willing to Pay a Premium to Stay at a "Green” Hotel? Evidence from an Internal Meta-Analysis of Hedonic Price Premia. Agricultural and Resource Economics Review, 39(3), 468-484.

Lee, S., Hsu, T., Han, H., \& Kim, Y. (2010). Understanding How Consumers View Green Hotels: How a Hotel's Green Image Can Influence Behavioral Intentions. Journal of Sustainable Tourism, 18(7), 901-914.

Lee, S., \& Oh, H. (2014). Effective Communication Strategies for Hotel Guests’ Green Behavior. Cornell Hospitality Quarterly, 55(1), 52-63.

Line, N., \& Hanks, L. (2015). The Effects of Environmental and Luxury Beliefs on Intention to Patronize Green Hotels: The Moderating Effect of Destination Image. Journal of Sustainable Tourism, 24(6), 904-925. doi:10.1080/09669582.2015.1091467

Manaktola, K., \& Jauhari, V. (2007). Exploring Consumer Attitude and Behavior Towards Green Practices in the Lodging Industry in India. International Journal of Contemporary Hospitality Management, 19(5), 364-377. doi:10.1108/09596110710757534

McGehee, N., \& Santos, C. (2005). Social Change, Discourse and Volunteer Tourism. Annals of Tourism Research, 32(3), 760-779.

Miao, L., \& Wei, W. (2013). Consumers' pro-environmental behavior and the underlying motivations: A comparison between household and hotel settings. International Journal of Hospitality Management, 32, 102-112. doi:10.1016/j.ijhm.2012.04.008

Millar, M., Mayer, K. J., \& Baloglu, S. (2012). Importance of green hotel attributes to business and leisure travelers. Journal of Hospitality Marketing and Management, 21(4), 395-413.

Muralidharan, S., Rejón-Guardia, F., \& Xue, F. (2016). Understanding the Green Buying Behavior of Younger Millennials from India and the United States: a Structural Equation Modeling Approach. Journal of International Consumer Marketing, 28(1), 54-72. doi:10.1080/08961530.2015.1056328 
Myung, E. (2016). Accepting Inconveniences for Environmentally Responsible Meetings An Exploratory Study. Journal of Hospitality and Tourism Management, 29, 112-118. doi:http://dx.doi.org/10.1016/j.jhtm.2016.06.004

Myung, E., McClaren, A., \& Li, L. (2012). Environmentally Related Research In Scholarly Hospitality Journals: Current Status and Future Opportunities. International Journal of Hospitality Management, 31(4), 1264-1275. doi:10.1016/j.ijhm.2012.03.006

Paul, J., Modi, A., \& Patel, J. (2016). Predicting Green Product Consumption Using Theory of Planned Behavior and Reasoned Action. Journal of Retailing and Consumer Services, 29, 123-134. doi:10.1016/j.jretconser.2015.11.006

Patton, M. Q. (2002). Qualitative research and evaluation methods. Thousand Oaks, CA: Sage.

Peach, M., Jimmieson, N., \& White, K. (2005). Beliefs Underlying Employee Readiness to Support a Building Relocation: a Theory of Planned Behavior Perspective. Organization Development Journal, 23(3), 9-22.

Rahman, I., Park, J., \& Chi, C. (2015). Consequences of "Greenwashing": Consumers' Reactions to Hotels' Green Initiatives. International Journal of Contemporary Hospitality Management, 27(6), 1054-1081. doi:10.1108/Ijchm-04-2014-0202

Rahman, I., \& Reynolds, D. (2016). Predicting Green Hotel Behavioral Intentions Using a Theory of Environmental Commitment and Sacrifice for the Environment. International Journal of Hospitality Management, 52, 107-116. doi:10.1016/j.ijhm.2015.09.007

Roulston, K. (2010). Reflective Interviewing: A guide to Theory and Practice. London, UK: Sage.

Siu, G., Lee, L., \& Leung, D. (2013). Residents' Perceptions Toward the “Chinese Tourists' Wave” in Hong Kong: An Exploratory Study. Asia Pacific Journal of Tourism Research, 18(5), 446-463.

Teng, Y., Wu, K., \& Liu, H (2015). Integrating Altruism and the Theory of Planned Behavior to Predict Patronage Intention of a Green Hotel. Journal of Hospitality \& Tourism Research, 39(3), 299-315. doi:10.1177/1096348012471383

Tierney, P., Hunt, M., \& Latkova, P. (2011). Do travelers support green practices and sustainable development. Journal of Tourism Insights, 2(2), 1-16.

White, K., \& Hyde, M. (2011). The Role of Self-Perceptions in the Prediction of Household Recycling Behavior in Australia. Environment and Behavior, 44(6), 785-799. 
Table 1

Socio-Demographic Composition of the Sample $(\mathrm{N}=15)$

\begin{tabular}{|c|c|c|}
\hline & & $\mathrm{n}$ \\
\hline Gender & Female & 8 \\
\hline & Males & 7 \\
\hline Age & 18 to 24 years old & 1 \\
\hline & 25 to 34 years old & 4 \\
\hline & 35 to 50 years old & 2 \\
\hline & Over 50 years old & 8 \\
\hline Profession & Administrative Worker & 1 \\
\hline & Clerical Worker & 1 \\
\hline & Community and personal service & 2 \\
\hline & Technicians and Trade Worker & 3 \\
\hline & Sales Worker & 1 \\
\hline & Professional & 2 \\
\hline & Retired & 3 \\
\hline & Home duties & 1 \\
\hline & Student & 1 \\
\hline
\end{tabular}


Table 2

Focus Group Guide Assessing Participants' Beliefs towards Staying at a Green Hotel.

\begin{tabular}{ll}
\hline Constructs & Questions \\
\hline General Questions & $\begin{array}{l}\text { "From your last trip, what environmental practices did you } \\
\text { notice in the hotel that you have stayed in?” } \\
\text { "What is the first thing that comes to your mind when you think } \\
\text { of a green hotel?” }\end{array}$ \\
\hline Behavioral Beliefs & $\begin{array}{l}\text { What are the benefits of staying at a green hotel when traveling } \\
\text { in the future? } \\
\text { What are the concerns of staying at a green hotel when traveling } \\
\text { in the future? }\end{array}$ \\
\hline Normative Injunctive & $\begin{array}{l}\text { Who of the people important to you would support your staying } \\
\text { at a green hotel when traveling in the future? }\end{array}$ \\
& $\begin{array}{l}\text { Who of the people important to you would not support your } \\
\text { staying at a green hotel when traveling in the future? }\end{array}$ \\
\hline Normative Descriptive & $\begin{array}{l}\text { Who of the people important to you are most likely to stay at a } \\
\text { green hotel when traveling in the future? }\end{array}$ \\
Weliefs & $\begin{array}{l}\text { Who of the people important to you are least likely to stay at a } \\
\text { green hotel when traveling in the future? }\end{array}$ \\
\hline Control Beliefs & $\begin{array}{l}\text { What would motivate you to stay at a green hotel when traveling } \\
\text { in the future? } \\
\text { What would prevent you to stay at a green hotel when traveling } \\
\text { in the future? }\end{array}$ \\
\hline Additional Constructs & $\begin{array}{l}\text { Are there any additional factors that would affect your decision } \\
\text { to stay at a green hotel in the future? }\end{array}$ \\
\hline
\end{tabular}


Major Categories, Beliefs (Including Number of Times Belief Listed in the Open Ended Questionnaires), and Example Quotations of Beliefs across the Full Sample $(\mathrm{N}=15))$.

\begin{tabular}{|c|c|c|}
\hline Category & Beliefs & Example Quotation \\
\hline \multirow[t]{4}{*}{ Behavioral Beliefs- Benefits } & Protecting the Environment $(n=9)$ & $\begin{array}{l}\text { "I believe that in staying at a green hotel I would help the environment as earth } \\
\text { should not pay the price for our actions". }\end{array}$ \\
\hline & Environmental Obligations $(n=5)$ & $\begin{array}{l}\text { "By staying at a green hotel, this would show how committed I am to the } \\
\text { environment". }\end{array}$ \\
\hline & Concern for Future Generation $(n=4)$ & $\begin{array}{l}\text { "If everyone initiated in booking at a green hotel, it would secure a positive } \\
\text { future for the next generations." }\end{array}$ \\
\hline & $\begin{array}{l}\text { Staying in a Healthy Environment } \\
(n=3)\end{array}$ & $\begin{array}{l}\text { "The green hotel practices makes me feel that I am staying in a healthy } \\
\text { environment." }\end{array}$ \\
\hline \multirow[t]{3}{*}{ Behavioral Beliefs- Concerns } & Greenwashing $(n=7)$ & $\begin{array}{l}\text { "I just wonder how environmentally friendly these hotels really are and what } \\
\text { happens behind the scenes." }\end{array}$ \\
\hline & Comfort $(n=4)$ & "I do not want to compromize my comfort by staying at a green hotel." \\
\hline & $\operatorname{Luxury}(n=4)$ & "For me staying at green hotel means that it will be likely to be less luxurious" \\
\hline
\end{tabular}

\section{Beliefs about the Expectations of Others Family/ Relatives $(n=7)$}

- Normative Belief Support
Younger Generation $(n=5)$

Colleagues $(n=5)$
"My family member would encourage me to stay at a green hotel."

"I guess the younger generation will be pushing to book at a green hotel because they are into that"

"I guess some of the encouragement would come from my colleagues." 


\begin{tabular}{|c|c|c|}
\hline $\begin{array}{l}\text { Beliefs about the Expectations of Others } \\
\text { - Normative Belief Unsupported }\end{array}$ & None $(n=7)$ & "None that I would know will not support my staying in a green hotel." \\
\hline \multirow{3}{*}{$\begin{array}{l}\text { Beliefs about the Behavior of Others- } \\
\text { Positive Behavior }\end{array}$} & Family/ Relatives $(n=5)$ & "I guess any of my relatives would stay in a green hotel." \\
\hline & Younger Generation $(n=4)$ & "Most of the young people I know would book in a green hotel." \\
\hline & Colleagues $(n=3)$ & $\begin{array}{l}\text { "Some of my work colleagues show interest in booking at environmentally } \\
\text { friendly hotels." }\end{array}$ \\
\hline $\begin{array}{l}\text { Beliefs about the Behavior of Others- } \\
\text { Negative Behavior }\end{array}$ & $\begin{array}{l}\text { Older Generation } \\
(n=4)\end{array}$ & $\begin{array}{l}\text { "I guess people older than me will not really care about staying at a green } \\
\text { hotel." }\end{array}$ \\
\hline \multirow[t]{2}{*}{ Control Beliefs -Facilitators } & Location $(n=8)$ & "The convenience of the location would definitely affect my decision." \\
\hline & Standardization $(n=7)$ & $\begin{array}{l}\text { "I have no clear idea about the green practices they conduct and if they are } \\
\text { following any standards." }\end{array}$ \\
\hline Control Beliefs -Barriers & High price $(n=13)$ & $\begin{array}{l}\text { "I do not think that I am totally ready to pay the extra price for staying at a } \\
\text { green hotel." }\end{array}$ \\
\hline Green Hotel Knowledge & Information $(n=13)$ & $\begin{array}{l}\text { "More understanding about the hotel's green practices would surely influence } \\
\text { me to choose between two hotels." }\end{array}$ \\
\hline
\end{tabular}

